Jesuit Libraries in the Old and the New Society of Jesus as a Historiographical Theme

Author: Noël Golvers

Source: Engaging Sources: The Tradition and Future of Collecting History in the Society of Jesus (Proceedings of the Symposium held at Boston College, June 11-13, 2019)

Edited by: Cristiano Casalini, Emanuele Colombo, and Seth Meehan

ISBN: 978-1-947617-09-4

Published by: Institute of Jesuit Sources

Originally Published: March 1, 2021

https://doi.org/10.51238/ISJS.2019.07

Provided in Open Access by the Institute for Advanced Jesuit Studies at Boston College.

The Institute of Jesuit Sources, specializes in preserving, maintaining, and expanding for scholars around the world important texts and studies in Jesuit history, spirituality, and pedagogy.

Visit our website at https://jesuitsources.bc.edu 


\title{
Jesuit Libraries in the Old and the New Society of Jesus as a Historiographical Theme
}

\author{
NOËL GOLVERS
}

Beginning with the spread of Christianity in late antiquity, the clergy became one of the social groups that collected books - classical pre-Christian and Christian titles alike - not only for immediate use but also for preserving and transmitting the literary tradition. The most famous, and influential, libraries may have been those of St. Augustine in Hippo Regius, Cassiodorus in Vivarium, and Pope Agapetus (r.535-36) in Rome. This tradition continued throughout the early Middle Ages, when abbeys and cloisters became almost the only sanctuaries of book culture.

Especially since early modern times and the rise of humanism, these monastic libraries were progressively accompanied by private book collections of "lay," humanistic scholars. Within the context of the Counter-Reformation, especially in Central Europe, many libraries acquired a new strategic purpose or were created "ex novo" as a weapon in the propaganda against the Reformation, leading to the emergence of the concept of Bibliothekenstrategie, a term coined by Heinrich Kramm. ${ }^{1}$ All these elements were resumed in the Society of Jesus (established 1540), in which books and libraries had a central place as part of a culture of instruction, edification, learning, and dissemination of the faith. Peter Canisius (1521-97) expressed this very well in his famous dictum: "I prefer a college without a proper church above a college without a library." "2 Through its engagement in a wide-ranging didactical program in the European and non-European missions and the enormous scriptural production of its members, the Society gave European book culture a new sense of vitality and opened up new horizons by bringing Western books and libraries to the West Indies and the Far East, creating new forms of mutual contact with very different cultures, which "returned" to the West in Jesuit reports and publications to Europe.

The Society's book culture was thoroughly organized, with general prescriptions and internal rules introduced on an almost global scale that shaped a true Jesuit book and library culture, as well as librarianship.

\footnotetext{
${ }^{1}$ Heinrich Kramm, Deutsche Bibliotheken unter dem Einfluss von Humanismus und Reformation (Leipzig: O. Harrassowitz, 1938), 93-98.

${ }^{2}$ Quoted from Canisius Epistulae, after László Buzás, Deutsche Bibliotheksgeschichte der Neuzeit (1500-1800) (Wiesbaden: Dr. Ludwig Reichert, 1976), 60. On Canisius and books, see Otto Braunsberger, "Ein Freund der Bibliotheken und ihrer Handschriften," in Scritti di storia e paleografia: Miscellanea Francesco Ehrle (Rome: Biblioteca Apostolica Vaticana, 1973), 5:455-72.

https://doi.org/10.51238/ISJS.2019.07

(C) Institute of Jesuit Sources, 2021
} 


\section{Jesuit Librarianship}

The Jesuit library was a by-product of the college, the cornerstone of the Society; ${ }^{3}$ the presence of a well-furnished library was a basic condition for a "domus" to receive the status of a collegium. Side by side with a "general" college library, specialized sub-collections often also arose within the walls of the Jesuit compound. These sub-collections were linked to particular "classes," such as, for example, the cubiculum mathematicum, that is, the mathematical class room, particular institutions, such as the pharmacy (pharmacopolium or botica), or to functions such as the local rector, the provincial, and so forth who kept special book collections in their room. Sometimes, sodalitates (sodalities) - especially in the southern Low Countries - also had their own libraries. Finally, there were individual room collections with items temporarily put at the disposal (ad usum) of one particular father, for one special purpose, such as studium privatum (private study). Even privately acquired books were ultimately given to the general library, at which point inventories were also made. ${ }^{4}$

The principles of Jesuit librarianship and its practices were written down first in the Regulae praefecti bibliothecae (1543 and 1583) 5 and in Coimbra (1545). These rules were later reshaped in more comprehensive and updated "textbooks" for a Jesuit library, such as those written by Claude Clément, Musei sive bibliothecae tam privatae quam publicae exstructio [...] (Lyon: J. Prost, 1635) (referring to the library of the Escorial [Madrid]); Jean Garnier, Systema bibliothecae Collegii Parisiensis Societatis Jesu (Paris: Sébastien Mabre-Cramoisy, 1678) (with reference to the library of the Parisian Collège de Clermont); Johann David Koeler,

\footnotetext{
${ }^{3}$ For the college library, see Dominique Julia, "La constitution des bibliothèques des collèges. Remarque méthodique," Revue d'histoire de l'église en France 83 (1997): 145-61.

${ }^{4}$ I am aware of two examples from the China mission, namely the personal library (c.280 titles) of the Japanese bishop in Macau, Diogo Valente (d.1633) (see Noël Golvers, "The Library Catalogue of Diogo Valente's Book Collection in Macau [1633]: A Philological and Bibliographical Analysis," Bulletin of Portuguese/Japanese Studies 13 [December 2006]: 7-43) and the inventories of the (Western and Chinese) book collection of Jean-François Foucquet in the Beitang, Beijing (c.1720), on which, see my: “'Bibliotheca in cubiculo': The 'Personal' Library of Western Books of Jean-François Foucquet, S.J. in Peking (Beitang, 1720) and the Intertextual Situation of a Jesuit Scholar in China," Monumenta serica 58 (2010): 249-80, and Nicolas Standaert, "Jean-François Foucquet's Contribution to the Establishment of Chinese Book Collections in European Libraries," Monumenta serica 63, no. 2 (2015): 361-424, here 361ff.

${ }^{5}$ See MHSI, Mon. Ignatiana, series 3tia, 4:58; Adrien Demoustier and Dominique Julia, Ratio studiorum: Plan raisonné et institution des études dans la Compagnie de Jésus (Paris: Bélin, 1997), passim (see index, s.v. "bibliothèque"; "livres"). See further Brendan Connolly, "The Roots of Jesuit Librarianship" (PhD diss., University of Chicago, 1955), 64ff.; Natale Vacalebre, Come le armadure e l'armi: Per una storia delle antiche biblioteche della Compagnia di Gesù; Con il caso di Perugia (Florence: L. Olschki, 2016), 50-52.

${ }^{6}$ Mathilde V. Rovelstad, "Claude Clément's Pictorial Catalog: A Seventeenth-Century Proposal for Physical Access and Literature Evaluation," Library Quarterly 61 (1991): 174-87.
} 
Sylloge aliquot scriptorum de bene ordinanda et ornanda bibliotheca (Frankfurt: Jo. Stein, 1728); and Michael Denis, Einleitung in die Bücherkunde (Vienna: Joh. Thomas Edl. v. Trattnern, k.k. Hofbuchdruckern und Buchhandlern, 1777-78) (referring to the Bibliotheca Garellia, later part of the Österreichische Nationalbibliothek).

Studies that deal with Jesuits and their books and libraries from a general perspective include Brendan Connolly, "The Roots of Jesuit Librarianship: 15401599” (PhD diss., University of Chicago, 1955) (which, on 126ff., also contains some sixteenth-century catalogs/inventories of Italian Jesuit residences), and Connolly, “Jesuit Library Beginnings," Library Quarterly 30 (1960): 243-52; Aurora Miguel Alonso, "La biblioteca de los Reales Estudios de San Isidro de Madrid" (PhD diss., Universidad Complutense de Madrid, 1996), 31-34; Natale Vacalebre, "“Como un hospital bien ordenado': Alle origini del modello bibliotecario della Compagnia di Gesù," Histoire et civilisation du livre 10 (2014): 51-68, and Vacalebre, Come le armadure e l'armi: Per una storia delle antiche biblioteche della Compagnia di Gesù; Con il caso di Perugia (Florence: L. Olschki, 2016), 33157; and Kathleen M. Comerford, "Jesuits and Their Books: Libraries and Printing around the World," Journal of Jesuit Studies 2, no. 2 (2015): 179-88.

\section{Particular Aspects and Practices}

There were two types of Jesuit college library: bibliotheca secreta or maior on the one hand and minor on the other, with the former referring to the "general" collection and the latter to sub-libraries. As well as books (including pergamena [books in parchment] and incunabula), both types of library also contained manuscripts. In addition, the term bibliotheca was to a certain extent also interchangeable with $\operatorname{Mus}(a)$ eum $^{7}$ - both terms could be substituted with each other precisely because most libraries were not purely "book collections" but were enriched with other intellectual paraphernalia.

Called praefectus bibliothecae or bibliothecarius, the Jesuit librarian was guided by a series of rules that set out his responsibilities. One of them was the selection of new books, for which he could rely on various sources of information; one source particularly aimed at Jesuit and other librarians was Philippe Labbe,

\footnotetext{
${ }^{7}$ See the title of Claude Clément, Musei sive bibliothecae tam privatae quàm publicae: Extructio, instructio, cura, usus; Libri IV (Lyon: Sumptibus Jacobi Prost, 1635); see also Jean Garnier, Systema bibliothecae Collegii Parisiensis Societatis Jesu (Paris: Sébastien Mabre-Cramoisy, 1678), 111ff. and the testimonies in André Masson, "La bibliothèque Temple des Muses au Dix-Septième Siècle," in Humanisme actif: Mélanges d'art et de littérature offerts à Julien Cain (Paris, Hermann, 1968), 2:133-39.
} 
Bibliotheca bibliothecarum pernecessaria omnibus bibliothecariis et quibuscumque librorum scientiarumque amatoribus, 2 nd ed. (Rouen, 1672). ${ }^{8}$

\section{Library Room Organization and the Classification, Disposition, and Location of the Books 9}

As an initial model, one could refer to the advice for an appropriate building or room given by Antonio Possevino in his Bibliotheca selecta, 1st ed. (Rome, 1593). In its first volume, the author advises selecting a room that is more elevated (elevatior) - in reality, often on the second floor - dry, and oriented toward the east in order to catch the morning sun. ${ }^{10}$ Yet original ground plans ("idea," "ichnographia") and other visual or descriptive representations of Jesuit libraries and their interior aspects are rare.

The books were located on shelves, constituting arcae — by preference from cypress wood - which were also called thecae, plutei, contabulata, librorum repositoria, or, in French, meuble. ${ }^{11}$ It was advised that they should be protected, after the model of the ancient Romans, by rubbing them with cedar oil and cleaning them at regular times.

Books would have been arranged in the separate armaria in a fixed order, according to classes based on their contents. Jesuit librarianship provided a more or less enduring system of classification, which was published in Possevino's Bibliotheca selecta and in the aforementioned books by Claude Clément (1635), Jean Garnier (1678), ${ }^{12}$ and Johann David Koeler (1728), among other works.

\footnotetext{
${ }^{8}$ See Lorenzo Mancini, "I bibliotecari del Collegio Romano (1551-1873): Un contributo per la storia delle biblioteche della Compagnia di Gesù," Archivum historicum Societatis Jesu 89, 177 (2020): 45-115.

${ }^{9}$ For Jesuit classifications, see Aurora Miguel Alonso, "El sistema clasificatorio de las bibliotecas de la Compañia de Jesus y su presencia en la bibliografia española," in Estudios sobre la Compañia de Jesús: Los jesuitas y su influencia en la cultura moderna (s. XVI-XVIII), ed. Javier Vergara Ciordia (Madrid: Universidad Nacional de Educación a Distancia, 2003), 361-422; Claude Jolly, "Naissance de la 'science' des bibliothèques," in Histoire des bibliothèques françaises: Tome 2, Les bibliothèques sous l'Ancien Régime, 1530-1789, ed. Claude Jolly (Paris: Promodis-Editions du Cercle du librairie, 1992), 381-85.

${ }^{10}$ Quod quoniam locum primo requirit, is fuerit editior \& humiditatis expers, sive ab ima parte, sive ab tectorum impluvio, atque ad Orientem vergens, ut Vitruvio placet (And because [the disposition of the books] first requires a room, this room should be a little bit more elevated, and free from humidity, either from the bottom side or from the roof's opening, [and] directed to the Orient, as it pleases Vitruv) (the reference is to Vitruvius, De architectura, $6,4,1)$.

${ }^{11}$ Cf. Roger Chartier and Daniel Roche, "Les pratiques urbaines de l'imprimé," in Histoire de l'édition française, ed. Roger Chartier and Henri-Jean Martin (Paris: Promodis, 1982), 2:521-58; see for this and other aspects of the furniture in French historical libraries, Claude Jolly in Histoire des bibliothèques françaises, 361-71 (esp. 364ff.: "mobilier et décors").

${ }^{12}$ On his classificatory system, see William Kane, "Jean Garnier, Librarian," Mid-America (April 1940): 191-222.
} 
Possevino subdivided the books into seven classes ${ }^{13}$ that became the basis of Jesuit classification, although further diversifications were later introduced according to the volume of the library's holdings and local specialties. Possevino's aim was to encourage the use of an agreeable room in which books were easily accessible, well ordered, well protected, and cared for. However, a more detailed and successful subdivision was proposed by Garnier, who identified four basic "parts," namely theology, philosophy, history, and law (eunomia), the former two subdivided into nineteen classes, the latter into thirty-one, all of which were further subdivided (e.g., "mathematics" into thirty, medicine into fifteen sub-classes, etc.).

Jesuit libraries were also decorated (ornatus) with other material, including astronomical or mathematical instruments, globes, statues, portraits or other visual objects, medallions, gems, and so on, ${ }^{14}$ while for larger instrument collections a separate room was preferred, such as in the Collège de Clermont in Paris. ${ }^{15}$

\section{Paupertas}

All these and other aspects of the library had to respect the spirit of paupertas, a material as well as an "ideological" expectation that regularly recurs in the descriptions of Jesuit libraries and was already found in the Constitutiones/Ordinationes with regard to writing in books. ${ }^{16}$ It therefore touches upon a basic principle of Jesuit collections.

One of the basic features of Jesuit and other libraries, which shaped the book collections into a library in the proper sense of the word, was the prescribed, systematic registration of each volume in an inventory or alphabetical catalog based on the authors' names. Beside the author's name, the catalog listed the title (abbreviated or not), the place and year of publication, the size, and its location in the library. Subsequently, a corresponding inscription was written in the volume in question, ${ }^{17}$ which referred to it being entered into the catalog following an almost

\footnotetext{
${ }^{13}$ Bibliotheca selecta, 48, 49.

${ }^{14}$ Claude Clément, Musei sive bibliothecae tam privatae quam publicae exstructio [...] (Lyon: J. Prost, 1635), 376-77. Sectio II. Caput I. Quaedam exquisita ad Musei perfectionem (Some refinements to the museum's perfection); Instrumenta mathematica (Mathematical instruments); Numismata antiqua (Ancient coins); Erudita rudera prisci temporis (Learned remnants of the early period); Quaedam naturae et artis miracula (Some natural and artificial wonders); Globus et sphaera in medio bibliothecae ne deesto (A [terrestrial] globe nor a [celestial] sphere should be absent in the center of the library).

${ }^{15}$ See Garnier, Systema bibliothecae Collegii Parisiensis, caput 5, 118: Propter tantam multitudinem magnitudinemque Bibliothecae spatio contineri non potuerunt (Because of the large number and size, they could not be contained within the library).

${ }^{16}$ Ordinationes (9: February 2, 1616): Ne paupertatis sanctae custodia, quae plurimum cordi nobis esse debet, ullâ ex parte violetur (Respect for poverty [...] should not be violated).

${ }^{17}$ In the late eighteenth-century library of the Collegio Romano, these "labels" were also printed: Ex Bibliotheca/majori Colleg(ii) Rom(ani)/Societa(atis) Jesu.
} 
uniform and mostly abbreviated formula of the following type: (inscriptus Catalogo) Collegii (alias Residentiae) Soc[ieta]tis Jesu, followed by the respective place name in its Latinate form in the genitive-locative case. This replicates almost literally the formula established and applied in the library of the Collegio Romano, which, owing to its central role in Jesuit instruction, imposed the original model. After the new book was adopted into the library's structure, the new item was sometimes first — and temporarily — disposed in a common room such as the recreation room to become known to the resident fathers.

The extant college inventories or catalogi and the auction catalogs made up after the suppression provide the most direct evidence for the reconstruction of a library's holdings. The catalogi were in principle handwritten and complete up until the time they were compiled (sometimes with the exclusion of the books from the "specialized" collections), but as unique manuscript documents they have often been lost, sometimes intentionally in order to counter imminent confiscation. Recent critical editions of catalogs are rare: for the La Flèche college, see Hervé Baudry, Une bibliothèque à la fin de l'ancien régime: Présentation historique, suivie de l'édition du catalogue des livres du Collège Royal de La Flèche (1777) (Chauray: Ligne d'ombre, 2015); for the Jesuit library of Perugia, see Vacalebre, Come le armadure e l'armi, 180-202; for Trento, see Claudio Fedele and Italo Franceschini, eds., La biblioteca del Collegio dei gesuiti di Trento: Pubblicazioni e manoscritti nelle biblioteche Trentine (Trento: Provincia autonoma di Trento. Soprintendenza per i beni librari e archivistici, 2007); for Gorizia, see Giuliana de Simone, La biblioteca del Collegium Goritiense S.I. (Baden-Baden: Valentin Körner, 2015-18). Many historical, mainly seventeenth-century catalogs from the Jesuit libraries in present-day Hungary have been edited in Magyarországi Jezsuita Kônyvtárak 1711-IG, vols. 1-2 (Szeged: n.p., 1990 and 1997); see also the critical edition of Alfredo Eduardo Fraschini and Luis Angel Sánchez's Index librorum bibliothecae Collegii Maximi Cordubensis Societatis Iesu 1757 (Buenos Aires, 2003).

In view of the auction, handwritten inventories were made up, and catalogs were printed in large numbers. They give the size of the library at the end of its history, but still it is an incomplete view of the original collection, because they were composed or printed after the collection had already been "screened" and selected. 
Particularly revealing are the auction catalogs of the Collège de Clermont ${ }^{18}$ and the professed house in Paris, ${ }^{19}$ the Collège Sainte Trinite in Lyon, ${ }^{20}$ the Colégio das Artes in Coimbra, ${ }^{21}$ and the Jesuit college of Munich. ${ }^{22}$

National overviews of catalog deposits, with archival indications, are given in the Historische Kataloge der Bayerischen Staatsbibliothek München (Wiesbaden: Harrasowitz 1996), 109ff. (with an inventory of a whole series of handwritten library catalogs of German Jesuit and other colleges, kept, since the early nineteenth century, in the Bayerische Staatsbibliothek [BSB] in Munich); for French Jesuit colleges, see Marie-Madeleine Compère and Dominique Julia, Les colleges français: XVIe-XVIIe siècle, vols. 1-2 (Paris: Institut national de recherche pédagogique; Centre national de la recherché scientifique, 1984 and 1988), sub no. $17 ;^{23}$ for auction catalogs relating to the Italian colleges, see Valentino Romani, “'Dispersione' vs 'disseminazione': Note e materiali per una storia delle biblioteche gesuitiche," in Le biblioteche private come paradigma bibliografico, ed. Fiammetta Sabba (Rome: n.p., 2008), 155-80, here 166-68 (Bologna, Modena, Palermo, Genova, Ferrara, Turin, etc.); for Sicily, see Le biblioteche dei gesuiti: Trecento anni di libri e cultura nella storia di Sicilia (Palermo: Centro Educativo Ignaziano. Biblioteca Centrale della Regione Siciliano, 2014); for an overview of the catalogs and inventories of Portuguese colleges, see Luana Giurgevich and Henrique Leitão, "Para um estudo das antigas bibliotecas jesuitas: Catalogos, inventarios e listas de livros," Brotéria 175 (2012): 161-68; a full inventory of the same-mostly kept in the Biblioteca Nacional de Portugal (BNP) and in the archives of Torre do Tombo (ANTT) - is listed by the same authors in Clavis Bibliothecarum (Lisbon: Moscavide, Secretariado Nacional para os Bens Culturais da Igreja, 2016), 295-317 (Bragança, Coimbra; Elvas, Evora; Lisbon [Colégio de Santo Antão; Casa Professa São Roque]; Santarem; Setubal, etc.); the holdings of former Polish Jesuit libraries are described by Ludwik Grzebień, Organizacja bibliotek Jezuickich w Polsce od XVI do XVIII wieku (Kraków: WAM Akademia

\footnotetext{
${ }^{18}$ Catalogue des livres de la bibliotheque des ci-devant soi-disans jésuites du Collége de Clermont: Dont la vente commencera le lundi 19 mars 1764 (Paris: Saugrain \& Leclerc, 1764); Catalogue des livres de la bibliothèque de la maison professe des ci-devant soi-disans jésuites (Paris: Pissot \& Gogué, 1763).

${ }^{19}$ Paris: AN X/1B 9695 ("Procès des jésuites").

${ }^{20}$ Catalogus librorum bibliothecae publicae Lugdunensis, qui in Collegio S[anctae] Trinitatis asservantur: BML MS 1460-62 (1767) and Catalogue de la bibliothèque du Grand Collège à Lyon, 1775: BML Fonds général, MS 1460-61 (1380).

${ }^{21}$ See the catalog entitled Livraria do collegio da Companhia de Jesus de Coimbra in Lisbon: ANTT, MNEJ, caixa 50, maço 61 (1766): cf. Luana Giurgevich and Henrique Leitão, Clavis Bibliothecarum: Catalogos e inventarios de livrarias de instituições religiosas em Portugal até 1834 (Lisbon: Moscavide, Secretariado Nacional para os Bens Culturais da Igreja, 2016), no. 710.

${ }^{22} \mathrm{BSB}, \mathrm{Cbm}$ Cat. 308a (end of the sixteenth century); 308c (1741) and 678 (1739).

${ }^{23}$ A digital project has started at the Archives Nationales de France (AN) called Catalogues de bibliothèques ecclésiastiques saisies pendant la période révolutionnaire (1770-1797); see http://bibale.irht.cnrs.fr (accessed November 16, 2020)
} 
Ignatianum, 2013); and for Croatia, see Marica Sapro-Ficovic and Zeljko Vegh, "The History of Jesuit Libraries in Croatia," Journal of Jesuit Studies 2, no. 2 (2015): 283-301.

\section{Ad usum: Books on Temporary Loan}

As already mentioned, not all the books acquired by the Jesuit librarian were stored in the general library, and inventories or catalogs were rarely made of specialized sub-collections. This was also the case for the books temporarily put at the disposal of one particular Jesuit, albeit in a limited number and for a restricted period of time; this practice of putting books ad usum was a continuation of pre-Jesuit monastic models - it was made official by a particular inscription in the volumes, and the temporary loans were listed in a separate document (also very rarely preserved); 24 periodically, Jesuit brothers responsible for the library controlled the rooms in order to retrieve items taken without authorization. ${ }^{25}$

\section{Analysis of Particular Collections and Their Holdings}

Another complementary approach to Jesuit librarianship focuses on the holdings of individual collections, which for various reasons has attracted much more systematic interest. These studies analyze the composition of the collection according to its contents, provenance, language, and chronology, converging occasionally in a history of the collection. Because of the highly uniform practices of Jesuit librarianship, these observations are mostly also valid for the general picture.

An exemplary analysis of this type is Wilfried Enderle's article on the former library of the Düsseldorf College in the Germanic lands in "Die Jesuitenbibliothek im 17. Jahrhundert: Das Beispiel der Bibliothek des Düsseldorfer Kollegs 1619-1773," Archiv für Geschichte des Buchwesens 41 (1994): 147212; for similar analyses, see Jürgen Coenen, "Die Bibliothek des ehemaligen Jesuitenkollegs in Münster," in Bibliothek in vier Jahrhunderten, ed. Helga Oesterreich (Münster: Aschendorf, 1988), 11-49; Dieter Breuer, "Die Aachener Jesuitenbibliothek," Geschichte im Bistum Aachen 6 (2002): 55-79; and Ian Holt,

\footnotetext{
${ }^{24}$ See, e.g., from the Jesuit college in Liège a Catalogus librorum commodatorum ex bibliotheca majori Societatis Jesu Leodiensis and the Catalogus bibliothecae majoris: Liber majoris bibliothecaelad inscribendos libros qui ad cubicula efferuntur, both in the library of ULg, MS 91c. The list of books "que el Padre Francisco Suarez tiene de la Universidad" (which Father Francisco Suárez keeps from the university) was published by Mario Brandão, "A livraria do Padre Francisco Suarez," Biblos (Coimbra) 3 (1927): 325-49.

${ }^{25}$ Fausto Sanches Martins, Jesuitas de Portugal: 1542-1759 (Porto: n.p., 2015), 128-34.
} 
"Die Solothurner Jesuitenbibliothek (1646-1773) und ihre Gönner," Jahrbuch für Solothurnische Geschichte 80 (2007): 247-77, where a series of other detailed studies on individual Jesuit libraries in Germany are also listed (Aachen, Münster, Trier, Porrentruy, Koblenz, Hildesheim, Mainz). For a more general picture, see also Heinrich Kramm, Deutsche Bibliotheken unter dem Einfluss von Humanismus und Reformation (Leipzig: O. Harassowitz, 1938), 93-98.

For the southern Low Countries, an analysis of the catalog and the holdings of the library of the Bollandist fathers (Patres hagiographi) in the Antwerp professed house 26 is made by Bart Op de Beeck in De Rosweyde aux Acta sanctorum: La recherché hagiographique des Bollandistes à travers quatre siècles, ed. Robert Godding et al. (Brussels: Société des Bollandistes, 2009), 154ff.

Useful observations on important historical French collections are contained in Paul Mech, "Les bibliothèques de la Compagnie de Jésus," in Histoire des bibliothèques françaises: Les bibliothèques sous l'ancien régime 1530-1789 (Paris: Promodis, 1988), 57-63; for the Collège de Clermont, see Gustave DupontFerrier, Du Collège de Clermont au Lycée Louis-le-Grand (1563-1920), tome I; Le collège sous les jésuites, 1563-1762 [...] (Paris: Brocard, 1921), 122ff.; André Tuilier, "Les origines du Collège Louis-le-Grand et de ses bibliothèques: II; Le collège à la fin du XVIe siècle au début du XVIIe siècle," in Mélanges de la bibliothèque de la Sorbonne 6 (1985): 21-45; for La Flèche, see, apart from Baudry, Louis Desgraves, "La bibliothèque du collège des jésuites à La Flèche," Revue française d'histoire du livre 56 (1987): 187-99; for Lyon, see Bertin Marion, Le Collège de la Trinité: Histoire d'une bibliothèque et de son cabinet de curiosités (Lyon: n.p., 2014).

As for Italy, on Bologna see Luigi Balsamo, "Le biblioteche dei gesuiti," in Gian Paolo Brizzi, "Inventario del fondo gesuitico conservato nell'Archivio dell'Ente Comunale di assistenza di Bologna," Atti \& memorie: Deputazione di storia patria per le provincie di Romagna, n.s., 20 (1969): 343-408, and Gian Paolo Brizzi and Anna Maria Matteucci, eds., Dall'isola alla città: I gesuiti a Bologna (Bologna: Nuova Alfa, 1988), 183-86; for Rome and the Collegio Romano, see Costanzo Bizzocchi, "La biblioteca segreta del Collegio Romano," Gesuiti della provincia Romana 3 (1971): 17-24, and Alfredo Serrai, "La bibliotheca segreta del Collegio Romano," Il bibliotecario: Rivista di biblioteconomia, bibliografia e scienze dell'informazione 2, no. 3 (2009): 17-50; for former Jesuit libraries in Tuscany, see Kathleen Comerford, "Jesuit Tuscan Libraries of the 1560s and 1570s: Bibliotheca Not Yet Selecta," Archivum historicum Societatis Iesu 81, no. 162

${ }^{26}$ The catalog of the printed books is preserved in Brussels: Museum Bollandianum, MS Boll. 2024. 
(2012): 515-31; for Perugia, see Vacalebre, Come le armadure e l'armi; for Palermo, see Antonino Lo Nardo, "Il Fondo Librario antico dei gesuiti a Palermo $[\ldots] .{ }^{27}$

For Spanish Jesuit collections, see Ratio studiorum: Una llibreria jesuitica a la Universitat de València (Valencia: Publicacions de la Universitat de València, 2001) (with many further bibliographic references to historical analyses of other Spanish Jesuit collections); Miguel Alonso Aurora, La biblioteca de los Reales Estudios de San Isidro de Madrid (su historia hasta la integracion en la Universidad Central) (Madrid: Publicaciones de la Fundación Universitaria Española, 1996). A highly detailed overview with bibliography on a series of other Spanish Jesuit libraries is contained in Julián Solana Pujalte, "El fondo del siglo XVI de la biblioteca del antiguo colegio de Santa Catalina de la Compañia de Jesus de Cordoba," Archivum historicum Societatis Iesus 151 (2007): 113-37, here 11416, and José J. Hernandez Palomo and José del Rey Fayardo, eds., Sevilla y America en la historia de la Companhia de Jesus: Homenaje al P. Franciso de Borja Medina Rojas, S.J. (Cordoba: CajaSur 2009); for Murcia, see Maria Victoria Jativa Miralles, La biblioteca del Colegio de San Esteban de los jesuitas de Murcia (Murcia: Editum, 2008); for Granada, see Inmaculada Arias de Saavedra, "La biblioteca de los jesuitas de Granada en el siglo XVIII: Una aproximacion," in Actas de al IV reunion cientifica de la Asociacion Española de Historia Moderna (Alicante: Universidad de Alicante. 1997), 609-26.

As for Portugal, see João Pereira Gomes, "As antigas livrarias dos jesuitas em Lisboa," Brotéria 40 (1945): 153-61; a short overview of the history of the Jesuit library in Évora is contained in Sousa Marques Pereira, "Vida e morte de uma biblioteca jesuita: A livraria grande do Colégio do Espirito Santo em Evora (1553-1777)."28 For an analysis of a historical Hungarian collection, see Gábor Farkas Farkas, "Il fondo antico della biblioteca dell'Università Eötvös Lorand di Budapest (1561-1635)," La bibliofilia: Rivista di storia del libro e di bibliografia 105 (2003): 49-76.

For a historical analysis of an English Jesuit library, see Hendrik Dijkgraaf, The Library of a Jesuit Community at Holbeck, Nottinghamshire (1679) (Cambridge: LP Publications, 2003).

\footnotetext{
${ }^{27}$ Presented at the Seminario di Studi, April 23, 2016, dall'Officina di Studi Medievali di Palermo: "Quod tantam librorum collegimus copiam."

${ }^{28}$ In As bibliotecas e o livro em instituições eclesiais: Actas do II e III encontro nacional (Lisbon: Moscavide, 2013), 118-32. The catalog is in ANTT-MNEJ, Maço 62, Cx. 50, no. 1.
} 


\section{Libraries and Acquisition Policy}

The holdings of the Jesuit libraries constantly needed to be updated with newly published books from an expanding European book market. ${ }^{29}$ The responsibility for doing so fell to the librarians and the local procurator, whereas the provision of new books for the libraries of missions beyond Europe, which was an inevitably complex task because of the difficulties in transporting them over long distances, was entrusted to the procurator missionum (Indiarum) or his socius (in Lisbon, Seville, Paris, Genoa, Antwerp, Munich). The acquisition of books had a budgetary aspect and happened within the framework of a yearly budget.

The budgetary aspect was an important element within the general college budget, and it also had consequences for the selection procedure. After an initial period in the sixteenth century, when books were bought from the college's global patrimony, a separate yearly rent for the library was later created. Budgetary data for European colleges are only irregularly preserved (as with many other aspects of Jesuit bookkeeping in general). ${ }^{30}$ However, for a series of data for the Italian colleges, see Romani, "'Dispersione' vs 'disseminazione," and Vacalebre, Come le armadure e l'armi.

This policy of purchase was necessarily complemented by a systematic search for doubles and triples in the libraries of other colleges, sometimes on the basis of circulating lists ${ }^{31}$ or through the libraries of local scholars. Indeed, it was part of the procurator's role to "incite" the donation of complimentary copies offered for free by their authors as a token of charity toward the church in general and the Society in particular, characterized as eleemosyna (alms). It was not only individual books that were offered but also entire libraries. ${ }^{32}$ As far as they are identified, the names of the donors-when indicated by an owner's inscription, mostly accompanied by an explicit formula of donation (ex dono; donatus; dado, etc.) - provide an original view of the rooting of a college in a local society and the participation of local representatives in the Jesuit projects, both locally and in the non-European missions. ${ }^{33}$

\footnotetext{
${ }^{29}$ On this aspect of Jesuit librarianship, see Natale Vacalebre, "I canali di acquisizione libraria negli ordini di chierici regolari: Il caso della Compagnia di Gesù," Bibliothecae.it 2 (2014): 187-202.

${ }^{30}$ For this type of source, see François de Dainville, "Livres de comptes et histoire de la culture," Archivum historicum Societatis Iesu 18 (1949): 226-52.

${ }^{31}$ Wilfried Enderle, "Die Jesuitenbibliothek im 17. Jahrhundert: Das Beispiel der Bibliothek des Düsseldorfer Kollegs 1619-1773," Archiv für Geschichte des Buchwesens 41 (1994): 147-212, here $181 \mathrm{n} 243$.

32 Enderle, "Die Jesuitenbibliothek im 17. Jahrhundert," 156.

${ }^{33}$ On the donors and benefactors of the library of the Collegio Romano, see Alfredo Serrai, "La bibliotheca secreta del Collegio Romano," Il bibliotecario 2, no. 3 (2009): 39-40; of the Collège de Clermont, see Garnier, Systema bibliothecae Collegii Parisiensis, 5f.; Gustave Dupont-Ferrier, Du Collège de Clermont au Lycée Louis-le-Grand (1563-1920), tome I; Le collège sous les jésuites,
} 


\section{Information and Selection ${ }^{34}$}

The selection of books was partly guided by lists recommended to the students, the novices, the tertians, and so on. ${ }^{35}$ These titles - mostly spiritual, meditative, or edifying "classics"-were handed over to the librarian/procurator to be bought, sometimes in more copies, to be distributed to the students. For new publications, especially in the sciences, the information was received through the current channels of communication, such as the correspondence between the Jesuit and other scholars, but also through the screening of booksellers' catalogs. ${ }^{36}$ Although lists of books and standing orders were sent from the missions, ${ }^{37}$ the procurator was often expected to buy books on his own initiative without previous requests from readers. As this must have exceeded his own knowledge, he was occasionally advised by non-Jesuit scholars: in Paris, for example, the French procurator Antoine Verjus (1632-1706) and his successors relied on the advice of scholars such as Gottfried Wilhelm Leibniz and Joseph-Nicolas Delisle for the acquisition of books for their fellow fathers in China. ${ }^{38}$

1563-1762 [...] (Paris: Brocard, 1921), 123-24, and Jean Cordey, "Le surintendant Fouquet et la bibliothèque du Collège de Clermont," Bibiothèque de l'Ecole des chartes 84 (1923): 347-54; of the Collège Sainte Trinité, see Bertin Marion, Le Collège de la Trinité: Histoire d'une bibliothèque et de son cabinet de curiosités (Lyon: n.p., 2014), 82-84; for Düsseldorf, see Enderle, "Die Jesuitenbibliothek im 17. Jahrhundert," 169n133; for the college of Louvain, see Leuven; Algemeen Rijksarchief, Archief van het Leuvens S.J. college, no. 20; for the college of Brussels, see KBR MS Inv. 4067: Catalogus benefactorum bibliothecae Collegii Societatis Jesu Bruxellae.

${ }^{34}$ See also Vacalebre, Come le armadure, p. $58 \mathrm{ff}$.

${ }^{35}$ Such lists had been circulating since the time of Everard Mercurian (1514-80, in office 157380); cf. further Joseph de Guibert, Spiritualité de la Compagnie de Jésus (Rome: Institutum Historicum S.J., 1953), 204ff. and my Libraries of Western Learning for China. Circulation of Western Books between Europe and China in the Jesuit Mission (ca. 1650-ca. 1750), vol. 1, Logistics of Book Acquisition and Circulation, Leuven Chinese Studies 23 (Leuven: F. Verbiest Institute, 2012), subheading 1.2.1.

${ }^{36}$ For example, the catalogues de libraire that Étienne Souciet sent to China with indications of books to his fellow-fathers in China: Paris: Observatoire, Biblioth., B 1.10 [150], 7.12. For a notebook with manuscript excerpts from library catalogs made by the librarian of the Jesuit college in Münster on the behalf of this library, see Jürgen Coenen, "Die Bibliothek des ehemaligen Jesuitenkollegs in Münster," in Bibliothek in vier Jahrhunderten, ed. Helga Oesterreich (Münster: Aschendorff, 1988), 11-49, here 25.

${ }^{37}$ Cf. Dominique Parrenin's list of 1731 preserved in Paris: AFSI, Brotier, vols. 110-22, fols. 44 46 (Renée Simon, Correspondance de Pékin, 1722-1759 [Geneva: Droz, 1970], 298-99); an explicit reference to standing orders is made in a joint letter of Antoine Gaubil and Dominique Parrenin from Beijing, dated September 22, 1732 and addressed to the "R(évérend) P(ère) Procureur, Paris"; see Simon, Correspondance de Pékin, 333.

38 Joachim Bouvet in 1703 (Rita Widmaier, Der Briefwechsel mit den Jesuiten in China (16891714) [Hamburg: F. Meiner Verlag, 2006], 389-90) and Antoine Gaubil on November 12, 1752 to astronomer Joseph-Nicolas Delisle (1688-1768), asking him to give his advice to the then "procureur" in Paris, Father Louis Alexis Le Houx (1698-1762); Simon, Correspondance de Pékin, 702. 
Books, even those from abroad, were acquired through local bookshops or through the network between the Jesuit colleges spread over Europe. Some documents inform us about the scale on which Jesuits or colleges bought books. From the perspective of the booksellers, the most revealing sources are the preserved account books of the Officina Plantiniana in Antwerp, which provide a highly detailed register of the purchases that the representatives of the colleges from the Provincia Flandro-Belgica made in the seventeenth and eighteenth centuries, including the date, the titles, and the prices they paid. Conversely, in the colleges, lists were also made of the books bought or received in a particular period, such as in the college of Lyon for books bought by the city of Lyon for the college in the period 167182.39

As for the material logistics of book shipment, this was mainly a problem when it came to transporting them over long distances and thus for the libraries in the East and West Indies. For the East Indies, I unraveled the system in Libraries of Western Learning for China: Circulation of Western Books between Europe and China in the Jesuit Mission (ca. 1650-ca. 1750), vol. 1, Logistics of Book Acquisition and Circulation (Leuven: F. Verbiest Institute, 2012); for the West Indies, the same has been studied - without a particular Jesuit approach — by Pedro J. Rueda Ramírez, Negocio e intercambio cultural: El comercio de libros con América en al Carrera de Indias (siglo XVII) (Seville: Universidad de Sevilla, 2005).

At the time of the suppression, the libraries of "stable" colleges spanned two and a half centuries of acquisition, even when the concentration over periods and domains was unequal, and the acquisition process was not linear. It seems that, at the end of this formation process, the larger colleges in Europe kept tens of thousands of volumes in the main ("general") library and its branches: by around 1870, for example, the Collegio Romano had about eighty thousand volumes; ${ }^{40}$ by 1678 , the Collège de Clermont in Paris already had thirty-two thousand, a figure that had risen to forty-seven thousand volumes by $1718 ; 41$ the Colegio Imperial in Madrid had between thirty and thirty-five thousand by the mid-eighteenth century; ${ }^{42}$ in the same period, Mainz had around thirty thousand; 43 in 1754, the professed house in

\footnotetext{
${ }^{39}$ Etat des livres achetés par la ville pour la bibliothèque du collège de la Trinité, depuis 1671 jusqu'en 1682: Lyon: Archives Municipales: GG 154 (Compère).

${ }^{40}$ Alfredo Serrai, "La bibliotheca secreta del Collegio Romano," Il bibliotecario 3, nos. 2/3 (2009): 17-50, here 26-28.

${ }^{41}$ Jean Garnier, Systema bibliothecae Collegii Parisiensis (Paris: S. Mabre-Cramoisy, 1678), 5; Gustave Dupont-Ferrier, Du Collège de Clermont au Lycée Louis-le-Grand (1563-1920) (Paris: E. De Boccard, 1925), 1:123.

${ }^{42}$ José Simón-Díaz, Historia del Colegio Imperial de Madrid (Madrid: Instituto de Estudios Madrilenos, 1992), 135-37.

${ }^{43}$ The data on Ingolstadt, Mainz, and Munich stem from Wilfried Enderle, "Die jesuitenbibliothek im 17. Jahrhundert: Das Beispiel des Düsseldorfer Kollegs 1619-1773," Archiv für die Geschichte des Buchwesens 14 (1994): 147-213, here 157.
} 
Paris had thirty thousand volumes; ${ }^{44}$ Munich had twenty-four thousand to twentyfive thousand; ${ }^{45}$ in the mid-seventeenth century, the professed house in Antwerp and the Jesuit College of Louvain were apparently the greatest in the southern Low Countries with 16,583 items; ${ }^{46}$ and, finally, as for colleges in Portugal, see the figures given by Luana Giurgevich. ${ }^{47}$ In the missions, most of the holdings were instead counted in the thousands rather than the tens of thousands, with the sole exceptions being the libraries of the Portuguese (Xitang/Nantang) and the French mission (Beitang) in Beijing.

\section{Jesuit Libraries in the Non-European Missions}

The missions in and outside Europe brought European culture to non-European countries, enabling an intercultural meeting between late humanistic and native cultures, while also bringing knowledge from "peripheral" worlds back to Europe through a steady stream of information, resulting in an early modern form of "global knowledge." From the late seventeenth century, this happened within an academic framework, as many Jesuits - especially in France - were members of the recently created Académie des Sciences.

This cross-cultural meeting was particularly fruitful in late Ming and early Qing China, which was considered as the mission most appropriate to the Jesuit Society because of the central position of books and learning within the Jesuit universe and in Chinese culture. ${ }^{48}$ It is no wonder, therefore, that beginning in the first decades of the seventeenth century, Nicolò Longobardo-probably following the suggestions of Matteo Ricci (d.1610) - launched a program aimed at acquiring large Western libraries in Beijing, with reference libraries in the other Jesuit residences and colleges. This plan was first implemented by Procurator Nicolas Trigault (1615-18) and his socius Johann Schreck. This basic collection, which arrived in China in 1618, was later updated with a more or less steady stream of new books until and even beyond the end of the mission, and from around 1690 it also included scholarly European periodicals. These books, which arrived through at least seven different routes (viae), were used to stock numerous libraries, including three in Beijing as well as other libraries in China. After the promulgation of antiChristian decrees (e.g., in 1724 by Emperor Yongzheng [r.1722-35]) and due to

${ }^{44}$ Louis Blond, La maison professe des jésuites (Paris: Ed. franciscaines, 1956), 53.

${ }^{45}$ Historische Kataloge, 300-1.

${ }^{46}$ Bart Op de Beeck, "Jezuïetenbibliotheken in de Zuidelijke Nederlanden: De liquidatie 17731828 " (PhD diss., KU Leuven, 2008), 223-24.

${ }^{47}$ As bibliotecas, 172-73.

${ }^{48}$ See Ferdinand Verbiest in his letter of August 15, 1678 in Noël Golvers, Letters of a Peking Jesuit: The Correspondence of Ferdinand Verbiest S.J. (1623-1688) (Leuven: Ferdinand Verbiest Institute, KU Leuven, 2017), 285. 
the general prohibition on proselytization, smaller book collections from the Chinese periphery and inland were gradually lost or became concentrated in Beijing. For testimonies on these Jesuit libraries in China, refer to my Libraries of Western Learning for China: Circulation of Western Books between Europe and China in the Jesuit Mission (ca.1650-ca. 1750), 3 vols. (Leuven: F. Verbiest Institute, 2012, 2013, 2015). My research shows that the Western books that arrived in China were far more numerous - despite the logistical difficulties involved - than estimated so far on the basis of the 4,100 extant volumes in the catalog of the "modern" (post1860) Beitang 49 and represented widely varied themes in accordance with the many tasks of the missionaries.

The general evidence on the formation of libraries in China-extant books, references in letters and treatises - speaks of the great efforts the Jesuits made until the end of the mission to keep the main collections in China up-to-date and representative, and that in favorable conditions books could arrive in China within a year after their appearance in Europe.

My research has also shown that in China the Western libraries were not only repositories of Western spirituality, experience, and knowledge (bibliothèques de travail) but also bibliothèques de combat: they provided the basis for polemics with various kinds of opponents and challengers. Finally, through their "exotic" aspects and the particular ornatus of the individual books (folio-size, gilded elements, scripture, illustrations), these libraries were also bibliothèques de prestige, with an immediate, positive impact on the position of the missionaries.

Here appears one last important aspect of these libraries: they were the scene where the real "meeting" and exchange of Western and Chinese knowledge took place, especially because these libraries were "doubled" by a Chinese library, and the number of Chinese books may have equaled, if not exceeded, that of Western books; ${ }^{50}$ at any rate, as the Jesuits' literary production from China proves, the presence of a Chinese and Western library created the circumstances for original cross-linguistic research and comparisons.

Jesuit books and libraries were also brought to other non-European missions, such as Japan, the West Indies, and Canada, but nowhere else did they equal the China mission, as nowhere else did the Jesuits meet a comparable, learned, and literary native culture.

Jesuit libraries in Japan - chronologically preceding those in China - were brought to Macau after the Japanese mission came to an end: see Jesus Lopez Gay, "La primer bibliotheca de los jesuitas en el Japon (1556)," Monumenta Nipponica 15 (1959): 350-79, and Rômulo da Silva Ehalt, "Revisiting the First Jesuit Library

\footnotetext{
${ }^{49}$ Hubert Verhaeren, Catalogue de la bibliothèque du Pé-tang (Beijng: Imprimeries de Lazaristes, 1949).

${ }^{50}$ See, e.g., Foucquet's room collection, which counted around three hundred Western books and more than a thousand Chinese titles.
} 
in Japan: An Analysis of the Purpose of Nunes Barretto's Library in Kyushu (1556)," Review of Culture (Macau) 32 (2009): 43-52.

For the Spanish West Indies, see Martin M. Morales, La libreria grande: Il fondo antico della Campagnia di Gesù in Argentina (Rome: Institutum Historicum Societatis Jesu, 2002); Benjamin Villegas, ed., Tesoros del colegio mayor de Nuestra Señora del Rosario: 350 años (Bogotá: Villegas editores, 2003), especially 2351 and 53ff.; Marisa Andrea Gorzalczany and Alejandro Olmos Gaona, La biblioteca jesuitica de Asuncion (Buenos Aires: Marisa Andrea Gorzalczany and Alejandro Olmos Gaona, 2006); Victoria O. Muñoz, "La biblioteca del colegio maximo de San Pablo de Lima (1568-1767): Una descripcion," Anuario del Archivo y biblioteca Nacionales de Bolivia 10 (2004): 817-28; Alfonso Rubio Hernandez, "Las librerias de la Compañia de Jesus en Nueva Granada: Un analisis descriptivo através de sus inventarios," Informacion, cultura y sociedad 31 (December 2014): 53-66, here 53ff.; Victoria O. Muñoz, "La biblioteca del colegio maximo de San Pablo de Lima (1568-1767): Una descripcion," Anuario del Archivo y biblioteca Nacionales de Bolivia 10 (2004): 817-28; Alfonso Rubio Hernandez, "Las librerias de la Compañia de Jesus en Nueva Granada: Un analisis descriptivo através de sus inventarios," Informacion, cultura y sociedad 31 (December 2014): 53-66; José del Rey Fajardo, "The Role of Libraries in the Missionary Regions of Orinoquia," Journal of Jesuit Studies 2, no. 2 (2015): 20822; on the collections in the college of Quito, see Joseph M. Barnadas, "La biblioteca jesuita de Quito en el siglo XVII: Breve panorama analitico," IberoAmericana Pragensia 8 (1974): 151-61.51

On Jesuit libraries in Brazil, see Luis F. Medeiros Rodrigues, “As 'livrarias' dos jesuitas no Brasil colonial, segundo os documentos do Archivum Romanum Societatis Iesu," Cauriensia 6 (2011): 275-302; Mark L. Grover, "The Book and the Conquest: Jesuit Libraries in Colonial Brazil," Libraries and Culture 28, no. 3 (1993): 266-83.

Historical Jesuit collections in Canada are presented by Antonio Drolet, "La bibliothèque du collège des jésuites," Revue d'histoire de l'Amérique française 14, no. 4 (1961): 487-544, and Janick Auberger, Quand les jésuites veulent comprendre l'Autre: Le témoignage de quelques livres anciens de la collection de l'UQAM (Quebec: n.p., 2012).

${ }^{51}$ See also Juan Navarro Loidi, "Los libros matematicos y cientificos de la biblioteca del colegio de los jesuitas de Quito (sec. XVII-XVIII)," Archives internationales d'histoire des sciences 52, no. 148 (2002): 198-211. 


\section{The End of the "Classical" Jesuit Libraries}

The end of these libraries coincided with the suppression of the Society, when the colleges (residences) to which they were directly connected were closed and the buildings destroyed or destined to a new destination either as a center of instruction (a university library, as in Genoa, or a municipal or state library, as in Rome with the Collegio Romano); elsewhere, the books were removed, diffused, and/or publicly sold, partly or "en bloc." In Portugal, this moment fell in the Pombal period (decree of September 3 1759); as for Macau and the China mission-part of the Padroado-Pombal's decree was only executed in 1762. In the rest of Catholic Europe, the suppression started in 1764 (France), 1767 (Spain), 1773 (the southern Low Countries), 1781 (Austrian territories ${ }^{52}$ ). For these public auctions, printed catalogs were made that were diffused in large numbers and are still to be found in most of the present-day European libraries.

Other critical moments were the Säkularisation ("secularization") in Bavaria in $1803^{53}$ and the confiscation in the early 1870 s of Jesuit (and other ecclesiastical) properties in the new Italian state. For the situation in Italy, see Romani, “'Dispersione' vs. 'disseminazione", for Rome and the Collegio Romano, see Costanzo Bizzocchi, "L'espropriazione della casa del Gesù in Roma nel 1873," in Gesuiti della provincia Romana (1973), fasc. 2, 1-11; for France, especially Paris and the Collège de Clermont (then Louis-le-Grand), see William Kane, "The End of a Jesuit Library," Mid-America: An Historical Review (July 1941): 190-212.

In the southern Low Countries (the former Provincia Flandro- and GalloBelgica), books from the Jesuit colleges were collected in the church of the former Jesuit college of Brussels and inventoried by Georges-Joseph Gérard (1734-1814): see Joseph Broeckaert, "Du sort des bibliothèques des jésuites dans les Pays-Bas," in Collection de précis historiques [...], 2nd series (Brussels: J. Vandereydt, 1875), 4:882ff., and more systematically Bart Op de Beeck, "Jezuïetenbibliotheken in de Zuidelijke Nederlanden: De liquidatie 1773-1828” (PhD diss., KU Leuven, 2008).

${ }^{52}$ Simon Laschitzer, "Die Verordnungen über die Bibliotheken und Archive der aufgehobenen Klöster in Oesterreich," Mittheilungen des Instituts für Oesterreichische Geschichtsforschung 2 (1881): 403-40.

${ }^{53}$ Cf. Hermann Hauke, "Die bedeutung der Säkularisation für die bayerischen Bibliotheken," in Glanz und Ende der alten Klöster: Säkularisation im bayerischen Oberland 1803, ed. Josef Kirmeier and Manfred Treml (Munich: Süddeutscher Verlag, 1981), 87-97. 


\section{Libraries in the "New Society"}

When the Society of Jesus was restored in 1814, the traditional organization was revitalized. Although the ancient locations and libraries were definitively lost, libraries regained their central position in the new Society and had in principle to be re-constituted ab ovo. The intriguing question of the extent to which ancient groups of books and documents were locally recuperated during this restoration process remains open; however, when it happened, the recuperation was an exception, due to private initiatives, as in the Vanves collection (AFSI) with the "fonds Brotier" (named after Gabriel Brotier, the last librarian of the Collège Louis-le-Grand); the manuscripts and around four thousand books of the Roman Jesuits "saved" by Superior General Pieter Jan Beckx (1795-1887, in office 1853-87); 54 and the "new" Museum Bollandianum (established 1837) in Brussels recuperated some materials from the previous Bollandist collections in the Antwerp professed house. ${ }^{55}$

New ideas on the position of Jesuit libraries are formulated in Joseph de Ghellinck, "Nos bibliothèques: Organisation, utilisation, conservation, gestion et direction," in Essais pédagogiques à l'usage exclusive des nôtres, 3rd series, vol. 2 (September 1931). As for cataloging, see Auguste Carayon, Catalogue systématique pouvant servir au placement méthodique d'une bibliothèque de trente à quarante mille volumes (Paris: Ch. Taranne, 1873; inspired by the Jesuit library of Poitiers).

For a general history of more recent Jesuit libraries in France, see Sheza Moledina, "L'histoire des bibliothèques jésuites à l'époque contemporaine, 18141998” (PhD diss., Villeurbane, L'Ecole normale supérieure des sciences de l'information et des bibliothèques, 2007).

Among the important "modern" collections was the library of Chantilly: Les Fontaines. Established in Laval in 1816 and transferred to Jersey in 1880, it was further expanded in Chantilly between 1951 and 1998 and transferred in 1998 to the Bibliothèque Municipale de Lyon (Part-Dieu) and Centre Sèvres (Paris); see Sheza Moledina, "La bibliothèque jésuite de Jersey: La constitution d'une bibliothèque en exil: 1880-1940" (http://www.enssib.fr/bibliothequenumerique/documents/1982-1); Moledina, "Books in Exile: The Case of the Jesuit Seminary Library in Jersey, 1880-1945," Library \& Information History 26, no. 2 (June 2010): $105-20$.

As for the Regis College Library (University of Toronto, established 1930), see Gordon Rixon, "Engaged Collecting: Culture Transforming Mission; The Regis

\footnotetext{
${ }^{54}$ On the bibliotheca privata P [atris] Petri Beckx, see Virginia Carini Dainotti, La biblioteca nazionale Vittorio Emanuele al Collegio Romano (Florence: L.S. Olschki, 1956), 1:61-62.

${ }_{55}$ Auguste Voisin, Documents pour servir à l'histoire des bibliothèques en Belgique (Ghent: C. Annoot-Braeckman, 1840), 163.
} 
College Library, Univ. of Toronto," Journal of Jesuit Studies 2, no. 2 (2015): 26582; for the Université St. Joseph in Beirut and its Bibliothèque orientale (established 1843), see Rafael Herzstein, "The Oriental Library and the Catholic Press at SaintJoseph University in Beirut," Journal of Jesuit Studies 2, no. 2 (2015): 248-64; for Xujiahui (Zikawei), Shanghai (established c.1860), see Huang Zhiwei, "Xujiawei cangshulou: The Xujiawei Library," Tripod 12, no. 70 (1992): 22-32; Gail King, "The Xujiahui (Zikawei) Library of Shanghai," Libraries \& Culture 32, no. 4 (1997): 456-69; on the reconstitution of its pre-1800 Western book collection, started by Father Claude Gotteland (1803-56) with purchases on the European antiquarian book market, see Noël Golvers, "Old Provenances of the Western Books in the Former (and Current) Xujiahui (Zikawei)-Library, Shanghai," Sino-Western Cultural Relations Journal 36 (2014): 25-43; for its Chinese holdings, see Nicolas Standaert, Ad Dudink 杜鼎克, and Wang Renfang 王仁芳, “Preface,” in Xujiahui cangshulou MingQing tianzhujiao wenxian xubian 徐家匯藏書樓明清天主教文 獻續編 (Sequel to Chinese Christian texts from the Zikawei library) (Taipei: Ricci Institute, 2013), 1:i-vii.

\section{Conclusion}

This contribution aimed to reconstitute the map of Jesuit libraries throughout the world, subsuming at the same time the many studies on individual Jesuit libraries, both historical and actual ones. Not surprisingly, these studies demonstrate their structural uniformity and their manifold functions (from being instruments of "public relations" to centers of study, translation, and production, as "open" collections interwoven with the regional context). The multiple phases of reconstitution and destruction of these libraries is also revealing in demonstrating the (mostly hidden, sometimes partly documented) continuity of the "modern" with the pre-suppression libraries. Being in some respects the heir of pre-Jesuit monastic practices, "classical" Jesuit librarianship prepared modern librarianship, and their libraries constituted the core of many modern "public" collections. As such, Jesuit libraries and librarianship, in Europe and in the missions, can be considered as the basis of modern librarianship and libraries. 